PROBLEMS OF NATIONAL PUBLIC AND PRIVATE LAW

DOI: 10.46340/eppd.2020.7.6.33

Oleksandra Spinchevska

ORCID ID: https://orcid.org/0000-0003-0750-6525

National Academy of Internal Affairs, Ukraine

\title{
PRACTICAL ASPECTS OF REALIZATION \\ OF JURISDICTIONAL POWERS \\ BY THE CONSTITUTIONAL COURT \\ OF UKRAINE
}

\author{
Олександра Спінчевська \\ Національна академія внутрішніх справ, Україна

\section{ПРАКТИЧНІ АСПЕКТИ РЕАЛІЗАЦЇ̈ \\ ЮРИСДИКЦЙНИХ ПОВНОВАЖЕНЬ КОНСТИТУЦЙНИМ СУДОМ УКРАЇНИ}

The article is devoted to the analysis of jurisdictional powers of the Constitutional Court of Ukraine enshrined in the current version of the Constitution of Ukraine and the Law of Ukraine "On the Constitutional Court of Ukraine», statistical indicators of its activity as a body of constitutional jurisdiction and some problematic issues that arise during the realization of these powers. They are connected, in particular, with: observance of formal requirements of the specified Law by subjects of the right on the constitutional complaint; observance by subjects of the right on the constitutional complaint and on constitutional petition of requirements of the mentioned Law concerning substantiation of the corresponding statements; observance of terms of constitutional proceedings in cases of constitutional petitions and constitutional complaints; execution and actual implementation of decisions and conclusions of the Constitutional Court of Ukraine; restoration of violated rights and freedoms of subjects of the right to a constitutional complaint after the Constitutional Court of Ukraine has made decisions in their cases.

Keywords: Constitutional Court of Ukraine, constitutional jurisdiction, jurisdictional powers, constitutional jurisdictional process, constitutional proceedings.

Постановка проблеми. Конституційний Суд України, виходячи 3 положень ч. 1 ст. 147 Конституції України та ст. 1 Закону України «Про Конституційний Суд України» від 13 липня 2017 року № 2136-VIII ${ }^{1}$ (далі- Закон), є органом конституційної юрисдикції, який забезпечує верховенство Конституції України, вирішує питання про відповідність Конституції України законів України та у передбачених Конституцією України випадках інших актів, здійснює офіційне тлумачення Конституції України, а також інші повноваження відповідно до Конституції України.

У процесуальній діяльності Конституційного Суду України щодо реалізації ним своїх юрисдикційних повноважень знаходить свій вияв конституційний юрисдикційний процес, який у широкому розумінні можна розглядати як комплекс нормативно врегульованих процесуальних відносин між органом конституційної юрисдикції та іншими суб'єктами права, які виникають у ході та результаті діяльності зазначеного органу та реалізації ним своїх повноважень, а у вузькому - як процесуальний порядок розгляду та вирішення органом конституційної юрисдикції справ у межах його компетенції, тобто конституційне провадження.

1 Закон про Конституиійний Суд України. 2017 (Верховна Рада України). Відомості Верховної Ради України, $35,376$. 
Результатом конституційної реформи правосуддя 2016 року $^{1}$ стали зміни, зокрема, змісту i обсягу юрисдикційних повноважень Конституційного Суду України, закріплених Основним Законом України, та порядку їх реалізації, встановленого Законом та Регламентом Конституційного Суду України $^{2}$ (далі - Регламент), що потребує відповідного аналізу. На сьогоднішній день Конституційним Судом України вже напрацьовано певну практику щодо зазначеного, окремі аспекти якої також буде досліджено у даній статті.

Аналіз останніх досліджень та публікацій. Окремим процесуальним аспектам діяльності Конституційного Суду України як органу конституційної юрисдикції присвячено праці І.Е. Берестової, В.Д. Бринцева, О.Ю. Водяннікова, В.О. Гергелійника, М.М. Гультая, Н.В. Камінської, В.М. Кампа, М.В. Костицького, О.М. Мироненка, А.В. Портнова, Х.В. Приходько, М.В. Савчина, А.О. Селіванова, В.С. Скоморохи, І.Д. Сліденка, А.А. Стрижака, М.В. Тесленко, Н.К. Шаптали та ін.

Виклад основного матеріалу. Внаслідок згаданої конституційної реформи правосуддя 2016 року із повноважень Конституційного Суду України вилучено офіційне тлумачення законів України, a із кола суб'єктів права на конституційне подання щодо офіційного тлумачення Конституції України виключено Кабінет Міністрів України, інші органи державної влади (крім передбачених ч. 2 ст. 150 Конституції України), органи місцевого самоврядування; Верховний Суд України замінено на Верховний Суд. Також набули нового сенсу конституційні звернення та переформатовано перелік підстав і вимоги до них. Інститут конституційного звернення у розумінні письмового клопотання громадян України, іноземців, осіб без громадянства та юридичних осіб до Конституційного Суду України про необхідність офіційного тлумачення Конституції України та законів України з метою забезпечення реалізації чи захисту конституційних прав та свобод людини і громадянина, а також прав юридичної особи, було ліквідовано і замінено конституційною скаргою, яка стала новим інструментом захисту конституційних прав і свобод людини і громадянина.

На сьогоднішній день Конституційний Суд України в порядку конституційного провадження, врегульованого розділом II Закону, розглядає справи за конституційними поданнями, конституційними зверненнями та конституційними скаргами. Актуальну уніфіковану класифікацію різновидів конституційного провадження, виходячи із встановлених Конституцією України та Законом повноважень Конституційного Суду України, суб'єктів звернення до нього та актів, які приймаються за результатами розгляду справи, може бути представлено у такому вигляді:

1) Провадження у справах за конституційними поданнями Президента України; щонайменше сорока п’яти народних депутатів України, Верховного Суду, Уповноваженого Верховної Ради України з прав людини, Верховної Ради Автономної Республіки Крим з питань ухвалення рішень щодо:

- вирішення питання про відповідність Конституції України (конституційність) законів та інших правових актів Верховної Ради України, актів Президента України, актів Кабінету Міністрів України, правових актів Верховної Ради Автономної Республіки Крим; України);

- офіційного тлумачення Конституції України (виходячи з положень ст. 150 Конституції

2) Провадження у справах за конституційними зверненнями з питань надання висновків щодо:

- відповідності Конституції України чинного міжнародного договору України або міжнародного договору, що вноситься до Верховної Ради України для надання згоди на його обов'язковість, суб'єктами якого є Президент України, або Кабінет Міністрів України, або щонайменше сорок п'ять народних депутатів України (виходячи з положень ч. 1 ст. 151 Конституції України);

- відповідності Конституції України (конституційності) питань, які пропонуються для винесення на всеукраїнський референдум за народною ініціативою, суб'єктами якого є Президент України або щонайменше сорок п’ять народних депутатів України (виходячи з положень ч. 2 ст. 151 Конституції України);

- додержання конституційної процедури розслідування і розгляду справи про усунення Президента України з поста в порядку імпічменту, суб'єктом якого є Верховна Рада України (виходячи 3 положень ч. 3 ст. 151 Конституції України);

\footnotetext{
1 Закон про внесення змін до Конституції України (щодо правосуддя). 2016 (Верховна Рада України). Відомості Верховної Ради України, 28, 532.

${ }^{2}$ Регламент Конституиійного Суду Украӥни, 2018 (Конституційний Суд України). Офіџійний сайт Конституиійного Суду України. <http://www.ccu.gov.ua/sites/default/files/reglament_2.pdf> (2020, жовтень, 07).
} 
- відповідності законопроекту про внесення змін до Конституції України вимогам ст. ст. 157 і 158 Конституції України, суб'єктом якого є Верховна Рада України (виходячи 3 положень ст. 159 Конституції України);

- порушення Верховною Радою Автономної Республіки Крим Конституції України або законів України, суб'єктом якого є Верховна Рада України (виходячи з положень п. 28 ч. 1 ст. 85 Конституції України);

- відповідності нормативно-правових актів Верховної Ради Автономної Республіки Крим Конституції України та законам України, суб'єктом якого $є$ Президент України (виходячи з положень ч. 2 ст. 137 Конституції України).

3) Провадження з питань ухвалення рішень у справах за конституційною скаргою особи, яка вважає, що застосований в остаточному судовому рішенні в її справі закон України суперечить Конституції України (виходячи 3 положень ст. $151^{1}$ Конституції України).

Аналіз статистичних показників щодо надходження різних видів звернень до Конституційного Суду України дає підстави стверджувати, що найчастіше ним реалізуються юрисдикційні повноваження щодо розгляду конституційних скарг, потім - щодо розгляду конституційних подань i конституційних звернень. Так, виходячи із даних, наведених у щорічних інформаційних доповідях Конституційного Суду України за 2017-2019 pр., у 2017 р. до Конституційного Суду надійшло 435 конституційних скарг (ще 39 надійшло у 2016 р., проте вони не розглядались у зв'язку з тим, що не було прийнято Закон), 30 конституційних подань і 2 конституційних зверненняя ; у 2018 р. - 690 конституційних скарг, 23 конституційних подання і 3 конституційних звернення ${ }^{2}$; у 2019 р. - 664 конституційні скарги, 21 конституційне подання і 8 конституційних звернень ${ }^{3}$. Станом на 8 жовтня 2020 р., за інформацією, наявною на офіційному веб-сайті Конституційного Суду України ${ }^{4}$, до Конституційного Суду України надійшло 453 конституційні скарги і 28 конституційних подань, конституційних звернень не надходило.

Конституційні звернення, які надходили до Конституційного Суду України у 2017-2019 рр., вносились Верховною Радою України і стосувались питань надання висновків щодо відповідності законопроекту про внесення змін до Конституції України вимогам ст. ст. 157 і 158 Конституції України. 3 інших питань, передбачених ст. 53 чинного Закону, конституційних звернень до Конституційного Суду України протягом зазначеного періоду та у 2020 році не надходило.

Стосовно проблемних моментів, які виникають у ході реалізації Конституційним Судом України своїх юрисдикційних повноважень, можна зазначити таке.

Недотримання формальних вимог Закону суб'єктами права на конституційну скаргу призводить до того, що Секретаріат Конституційного Суду України за результатами перевірки спеціально створеним у його структурі Управлінням документального забезпечення та попередньої перевірки конституційних скарг повертає значну кількість таких клопотань їх авторам. Так, у 2017 р. суб'єктам права на конституційну скаргу було повернуто 367 клопотань (77 \% від загальної кількості) $)^{5}$, у 2018 р. - 426 (62\% від загальної кількості) $)^{6}$, 2019 р. - 359 (54\% від загальної кількості). Станом на 8 жовтня 2020 р. повернуто 255 конституційних скарг (56 \% від загальної кількості) ${ }^{7}$.

\footnotetext{
${ }^{1}$ Постанова Про Щорічну інформаційну доповідь Конституиіийного Суду Украӥни за 2017 рік, 2018 (Конституційний Суд України). Конституційний Суд Украӥни Офіиійний вебсайт <http://www.ccu.gov.ua/sites/default/files/dopovid_2017.pdf> (2020, жовтень, 07).

${ }^{2}$ Постанова Про Щорічну інформачійну доповідь Конституиійного Суду Украйни за 2018 рік, 2019 (Конституційний Суд України). Конституційний Суд Украӥни Офіџійний вебсайт <http://www.ccu.gov.ua/sites/default/files/dopovid_2018.pdf> (2020, жовтень, 07).

${ }^{3}$ Постанова Про Щорічну інформачійну доповідь Конституиійного Суду Украйни за 2019 рік, 2020 (Конституційний Суд України). Конституиійний Суд Украӥни Офічійний вебсайт <http://www.ccu.gov.ua/sites/default/files/dopovid_2019.pdf> (2020, жовтень, 07).

${ }^{4}$ Офіційний веб-сайт Конституційного Суду України (2020). Головна сторінка <http://www.ccu.gov.ua> (2020, жовтень, 07).

${ }^{5}$ Постанова Про Щорічну інформачійну доповідь Конституиійного Суду Украӥни за 2017 рік, 2018 (Конституційний Суд України). Конституційний Суд Украӥни Офіиійний вебсайт <http://www.ccu.gov.ua/sites/default/files/dopovid_2017.pdf> (2020, жовтень, 07).

${ }^{6}$ Постанова Про Щорічну інформачійну доповідь Конституиійного Суду Украйни за 2018 рік, 2019 (Конституційний Суд України). Конституиійний Суд Украӥни Офічійний вебсайт <http://www.ccu.gov.ua/sites/default/files/dopovid_2018.pdf> $(2020$, жовтень, 07).

${ }^{7}$ Офіційний веб-сайт Конституційного Суду України (2020). Головна сторінка <http://www.ccu.gov.ua> (2020, жовтень, 07).
} 
Можна констатувати, що незважаючи на позитивну динаміку, кількість конституційних скарг, які повертаються їх авторам, все ще $є$ досить значною.

Ще одним проблемним моментом є недотриманням суб'єктами звернень вимог Закону щодо обгрунтування відповідних тверджень у справах за конституційними скаргами (п. 6 ч. 2 ст. 55), що вказує на неприйнятність такої скарги і $є$ підставою для відмови у відкритті конституційного провадження згідно 3 п. 4 ст. 62 Закону, та конституційними поданнями (ч. 3,4 ст. 51), що $є$ підставою для відмови у відкритті конституційного провадження згідно з п. 3 ст. 62 Закону - невідповідність конституційного подання вимогам, передбаченим Законом. Так, 2019 р. Конституційним Судом України було постановлено 286 ухвал про відмову увідкритті конституційного провадження у справах за конституційними скаргами (сенатами - 16, колегіями суддів - 270). Найчастіше підставою для відмови у відкритті конституційного провадження за конституційними скаргами визнавалася їх неприйнятність, про що було зазначено у 249 ухвалах колегій суддів та 13 ухвалах сенатів. При цьому головною причиною неприйнятності конституційних скарг, за оцінкою Конституційного Суду України, була відсутність обгрунтування тверджень щодо неконституційності закону України (його окремих положень) із зазначенням порушеного права людини, гарантованого Конституцією України; про це зазначено у 220 ухвалах колегій суддів та в 10 ухвалах сенатів. Із 9 ухвал про відмову у відкритті конституційного провадження, постановлених 2019 р. Конституційним Судом України у справах за конституційними поданнями, 5 було постановлено 3 підстав невідповідності клопотання вимогам, передбаченим законом, i 2 - зпідстав неналежності до повноважень Конституційного Суду України питань, порушених у клопотанні, та невідповідності клопотання вимогам, передбаченим законом, одночасно ${ }^{1}$.

Відповідно до положень ч. 1, 2 ст. 75 Закону строк конституційного провадження, обчислення якого ведеться 3 дня постановлення ухвали про відкриття конституційного провадження у справі, а у разі відмови Сенату від розгляду справи на розсуд Великої палати - здня постановлення відповідної ухвали Сенату, не повинен перевищувати шість місяців, якщо інше не встановлено цим Законом. Згідно з ч. 3 ст. 75 Закону для справ про надання висновку щодо відповідності законопроекту про внесення змін до Конституції України вимогам ст. ст. 157 і 158 Конституції України; за зверненням Президента України щодо конституційності актів Кабінету Міністрів України відповідно до п. 15 ч. 1 ст. 106 Конституції України; щодо яких Сенат, Велика палата визнали конституційне провадження невідкладним, строк конституційного провадження не може перевищувати один календарний місяць. Проте Конституційний Суд України не завжди дотримується зазначених строків конституційного провадження у справах за конституційними поданнями та конституційними скаргами. Зокрема, ним дотепер розглядається справа за конституційними поданнями Верховного Суду України та 47 народних депутатів України щодо відповідності Конституції України (конституційності) окремих положень Закону України «Про очищення влади», які Ухвалою від 6 липня 2017 р. № 5-уп/2017² було об’єднано в одне конституційне провадження. 3 одного боку, така значна затримка у розгляді зазначених подань може бути обумовлена складністю порушених у них питань. 3 іншого боку, із плином часу змінюються суспільно-політичні обставини, нормативне регулювання та можуть втрачатися нагальність і актуальність питань, порушених у відповідних клопотаннях. Так, у результаті конституційної реформи правосуддя 2016 року Верховний Суд України, який був суб'єктом права на конституційне подання у зазначених клопотаннях, було фактично ліквідовано, натомість створено Верховний Суд. Змінилась розстановка політичних сил: 2019 р. було обрано нового Президента України та новий склад Верховної Ради України. Європейський суд з прав людини у справі «Полях та інші проти України» ${ }^{3}$, яка стосувалась звільнення п’яти державних службовців на підставі оспорюваних положень Закону України «Про

\footnotetext{
${ }^{1}$ Постанова Про Щорічну інформаційну доповідь Конституиіийного Суду України за 2019 рік, 2020 (Конституційний Суд України). Конституційний Суд Украӥни Офічійний вебсайт <http://www.ccu.gov.ua/sites/default/files/dopovid_2019.pdf> (2020, жовтень, 07).

2 Ухвала про об' єднання конституційних проваджень у справах за конституційними поданнями Верховного Суду України щзодо відповідності Конституиії України (конституиійності) пункту 6 частини периої, пунктів 2, 13 частини другої, частини третьої статті 3 Закону Украӥни «Про очищення влади», 2017. (Конституційний Суд України) Конституиійний Суд Украӥни Офіиійний вебсайт <http://www.ccu.gov.ua/sites/default/files/docs/5_yn_2017.pdf>(2020, жовтень, 07)

${ }^{3}$ Полях та інші проти Украӥни, 2019 (Свропейський Суд з Прав Людини). Офіційний сайт Верховної Ради України <https://zakon.rada.gov.ua/laws/show/974_e71\#Text>(2020, жовтень, 07)
} 
очищення влади», ухвалив рішення від 17 жовтня 2019 р. на користь заявників. Ухвалою від 12 березня 2020 р. № 1-уп/2020 Конституційний Суд України поновив розгляд зазначеної справи на відкритій частині пленарного засідання у формі усного провадження для з'ясування додаткових обставин, які мають істотне значення для іiі вирішення, проте рішення уданій справі ним досі не ухвалено.

Проблема $з$ дотриманням строків конституційного провадження актуальна також і щодо розгляду Конституційним Судом України справ за конституційними скаргами. Хоча вони і почали надходити до Конституційного Суду України наприкінці 2016 р., Суд не розглядав їх до прийняття Закону та Регламенту. Перше рішення у справі за конституційною скаргою було ухвалено ним лише на початку 2019 року; у 2019 році Сенатами та Великою палатою було ухвалено 9 рішень у справах за конституційним скаргами ${ }^{1}$, станом на 8 жовтня 2020 р. -10 рішень $^{2}$, причому здебільшого конституційне провадження у справах тривало довше передбачених Законом шести місяців. Зазначені затримки може бути обумовлено новизною даного інституту для Конституційного Суду України.

Існують також певні труднощі, пов'язані з виконанням чи реалізацією рішень і висновків Конституційного Суду України. У ході здійснення Конституційним Судом України повноважень щодо розгляду конституційних звернень з питань надання висновків щодо відповідності законопроекту про внесення змін до Конституції України вимогам ст. ст. 157 і 158 Конституції України, які в основному й розглядаються ним, переважно не виникає проблем із дотриманням вимог Закону суб'єктами звернення, строків конституційного провадження та реалізацією відповідних висновків Суду. Щодо інших різновидів конституційних звернень відповідно до чинного Закону практика Конституційного Суду України наразі відсутня. Водночас слід зауважити, що до прийняття Закону Конституційний Суд України розглядав щодо вказаних питань конституційні подання у порядку, передбаченому Законом 1996 року, і тут можна відзначити деякі проблемні моменти.

Так, прикладом реалізації Конституційним Судом України повноваження стосовно надання висновку щодо відповідності Конституції України чинного міжнародного договору України або міжнародного договору, що вноситься до Верховної Ради України для надання згоди на його обов'язковість, $\epsilon$ Висновок у справі про Римський Статут № 3-в/2001 ${ }^{3}$, який було дано ним 11 липня 2001 р. У абзацах п’ятому, шостому підпункту 2.1 пункту 2 зазначеного Висновку Конституційний Суд України вказав, що «на відміну від міжнародних судових органів, передбачених частиною четвертою статті 55 Конституції України, які за своєю природою є допоміжними засобами захисту прав і свобод людини і громадянина, Міжнародний кримінальний суд доповнює систему національної юрисдикції. Можливість такого доповнення судової системи України не передбачена розділом VIII «Правосуддя» Конституції України. Це дає підстави для висновку, що абзац десятий преамбули та стаття 1 Статуту не узгоджуються з положеннями частин першої, третьої статті 124 Конституції України, а тому приєднання України до цього Статуту відповідно до частини другої статті 9 Конституції України можливе лише після внесення до неї відповідних змін». У ході конституційної реформи правосуддя 2016 р. статтю 124 Конституції України було викладено в новій редакції; відповідно до частини шостої зазначеної статті, яка набрала чинності з 30 червня 2019 р., Україна може визнати юрисдикцію Міжнародного кримінального суду на умовах, визначених Римським статутом Міжнародного кримінального суду. Проте Римський статут досі не ратифіковано Україною.

Конституційний Суд України Рішеннями від 14 березня 2014 р. № 2-рп/20144 і від 20 березня 2014 p. № 3-рп/20145 визнав постанови Верховної Ради АР Крим «Про проведення

\footnotetext{
${ }^{1}$ Постанова Про Щорічну інформачійну доповідь Конституичійного Суду Украӥни за 2019 рік, 2020 (Конституційний Суд України). Конституційний Суд Украӥни Офіційний вебсайт <http://www.ccu.gov.ua/sites/default/files/dopovid_2019.pdf> (2020, жовтень, 07).

2 Офіційний веб-сайт Конституційного Суду України (2020). Головна сторінка <http://www.ccu.gov.ua> (2020, жовтень, 07).

${ }^{3}$ Висновок по справі про Римський Статут, 2001 (Конституційний Суд України). Конституційний Суд Украӥни Офіиійний вебсайт <http://www.ccu.gov.ua/docs/350> (2020, жовтень, 07).

${ }^{4}$ Рішення у справі про проведення місцевого референдуму в Автономній Республіці Крим, 2014 (Конституційний Суд України). Конституційний Суд Украӥни Офіиійний вебсайт <http://www.ccu.gov.ua/sites/default/files/ndf/2-rp/2014.pdf> (2020, жовтень, 07).

5 Рішення у справі щзодо відповідності Конституиії Украӥни (конституційності) Постанови Верховної Ради
} 
загальнокримського референдуму» від 6 березня 2014 р. № 1702-6/14 та „Про Декларацію про незалежність Автономної Республіки Крим і міста Севастополя“ від 11 березня 2014 р. № 1727-6/14 такими, що не відповідають Конституції України (є неконституційними). Проте, незважаючи на це, загальнокримський референдум було проведено, наслідком чого стало входження Автономної Республіки Крим до складу Російської Федерації як ії суб'єкта, а фактично - анексія Автономної Республіки Крим Російською Федерацією. Зазначене вказує на невиконання цих рішень та ставить під сумнів можливість реалізації Конституційним Судом України повноважень, передбачених п. п. 5, 6 ч. 1 ст. 53 Закону стосовно розгляду ним питань за конституційними зверненнями щодо порушення Верховною Радою Автономної Республіки Крим Конституції України або законів України, суб'єктом якого є Верховна Рада України (виходячи з положень п. 28 ч. 1 ст. 85 Конституції України); та щодо відповідності нормативно-правових актів Верховної Ради Автономної Республіки Крим Конституції України та законам України, суб'єктом якого є Президент України (виходячи з положень ч. 2 ст. 137 Конституції України).

Iз 19 рішень, ухвалених Конституційним Судом України у справах за конституційними поданнями та за конституційними скаргами у 2019 р., виконано/частково виконано 6 рішень, не виконано 6 рішень, 7 рішень не потребують спеціальних заходів щодо їх реалізації. Станом на 31 грудня 2019 року залишалися нереалізованими 15 рішень Конституційного Суду України, що мають істотне суспільне значення, ухвалених ним до 1 січня 2019 p. ${ }^{1}$ Ст. 98 Закону визначено, що за невиконання рішень та недодержання висновків Конституційного Суду України настає відповідальність згідно із законом. Таку відповідальність передбачено ч. 4 ст. 382 Кримінального кодексу України ${ }^{2}$ (умисне невиконання службовою особою рішення Європейського суду з прав людини, рішення Конституційного Суду України та умисне недодержання нею висновку Конституційного Суду України). Проте наразі практика притягнення до відповідальності за невиконання рішень чи недодержання висновків Конституційного Суду України відсутня.

Важливим також $є$ питання можливості відновлення порушених прав і свобод суб'єктів права на конституційну скаргу після ухвалення Конституційним Судом України рішень у їх справах. Так, згідно з положеннями Господарського процесуального кодексу України ${ }^{3}$, Цивільного процесуального кодексу України ${ }^{4}$, Кодексу адміністративного судочинства України ${ }^{5}$ встановлена Конституційним Судом України неконституційність (конституційність) закону, іншого правового акта чи їх окремого положення, застосованого (не застосованого) судом при вирішенні справи, є однією з підстав для перегляду судових рішень у зв'язку з виключними обставинами, якщо рішення суду ще не виконане; відповідну заяву може бути подано учасниками справи протягом тридцяти днів 3 дня офіційного оприлюднення відповідного рішення Конституційного Суду України. Аналогічні положення містить і Кримінальний процесуальний кодекс України ${ }^{6}$. Проте оскільки зазвичай на момент ухвалення відповідних рішень Конституційним Судом України судові рішення у справах суб'єктів права на конституційну скаргу вже виконані, а Конституція України та Закон не передбачають можливості

Автономної Республіки Крим «Про Декларацію про незалежність Автономної Республіки Крим і міста Севастополя», 2014. (Конституційний Суд України). Конституційний Суд України Офіційний вебсайт <http://www.ccu.gov.ua/sites/default/files/ndf/3-rp/2014.pdf> (2020, жовтень, 07).

${ }^{1}$ Постанова Про Щорічну інформачійну доповідь Конституиійного Суду Украйни за 2019 рік, 2020

(Конституційний Суд України). Конституиійний Суд Украӥни Офіційний вебсайт

<http://www.ccu.gov.ua/sites/default/files/dopovid_2019.pdf > (2020, жовтень, 07).

${ }^{2}$ Кримінальний кодекс, ч. 4 cm.. 382, розд. XVIII, 2001 (Верховна Рада України). Офіиійний сайт Верховної

Ради України. <https://zakon.rada.gov.ua/laws/show/2341-14\#Text> (2020, жовтень, 07).

${ }^{3}$ Господарський процесуальний кодекс, n. 1 ч. 3 cm. 320, n. 4 ч. 1 cm. 321, розд. IV, гл. 3. 1991 (Верховна Рада

України). Офіиійний сайт Верховної Ради Украӥни. <https://zakon.rada.gov.ua/laws/show/1798-12\#Text> (2020, жовтень, 07).

${ }^{4}$ Цивільний прочесуальний кодекс, $n .1$ ч. $3 \mathrm{~cm} .423, n .4$ ч. 1 cm. 424, розд. V, гл. 3. 2004 (Верховна Рада України). Офіційний сайт Верховної Ради Украӥни. 〈https://zakon.rada.gov.ua/laws/show/1618-15\#Text> (2020, жовтень, 07).

${ }^{5}$ Кодекс адміністративного судочинства, n. 1 ч. 5 cm. 361, n. 4 ч. 1 cm.363, розд. III, гл. 3.2005 (Верховна Рада України). Офіційний сайт Верховної Ради України. 〈https://zakon.rada.gov.ua/laws/show/2747-15\#Text> (2020, жовтень, 07).

${ }^{6}$ Кримінальний процесуальний кодекс, n. 1 ч. 3 cm. 459, n. 1 ч. 5 cm. 461, розд. V, гл. 34. 2012 (Верховна Рада України). Офіційний сайт Верховної Ради України. 〈https://zakon.rada.gov.ua/laws/show/4651-17\#Text> (2020, жовтень, 07). 
зворотної дії рішень Конституційного Суду України у часі, відновлення попереднього юридичного стану, який передував застосуванню судом у процесі вирішення справи правового акта чи його окремого положення, надалі визнаного органом конституційної юрисдикції таким, що не відповідає Конституції України, $є$ нездійсненним ${ }^{1}$. Вирішення даної проблеми можливе лише шляхом внесення відповідних змін до Основного Закону України.

Слід зауважити, що ст. 78 Закону передбачено, що при розгляді конституційної скарги Велика палата, у виняткових випадках, з власної ініціативи може вжити заходів щодо забезпечення конституційної скарги, видавши забезпечувальний наказ, який є виконавчим документом; підставою для забезпечення конституційної скарги $\epsilon$ необхідність запобігти незворотнім наслідкам, що можуть настати узв'язку з виконанням остаточного судового рішення; способом забезпечення конституційної скарги є встановлення тимчасової заборони вчиняти певну дію; забезпечувальний наказ втрачає чинність здня ухвалення рішення або постановлення ухвали про закриття конституційного провадження у справі. Наразі Велика палата Конституційного Суду України застосувала даний процесуальний інститут лише одного разу - забезпечувальний наказ було видано нею 16 квітня 2019 р. у справі за конституційною скаргою Дерменжи А.В. щодо відповідності Конституції України (конституційності) положень частин першої, другої статті 23 Закону України «Про іпотеку». Ним було встановлено заборону здійснювати звернення стягнення на предмет іпотеки, а саме квартиру, яка належала скаржнику, який у своєму клопотанні стверджував, що «у разі виконання остаточного судового рішення, яким звернено стягнення на його квартиру, він та його родина фактично опиняться на вулиці без житла та без коштів».

Дане рішення Конституційного Суду України було сприйнято неоднозначно. Так, О.Ю. Водянніков зазначив, що якщо внаслідок визнання закону чи його положення неконституційним, можливий поворот виконання, тобто повне або часткове відновлення первісного становища особи, що передувало виконанню судового рішення, або застосування інших механізмів відновлення прав особи, то апріорі не може бути «незворотних наслідків» в сенсі ст. 78 Закону і забезпечувальний наказ є безпідставним. У справі ж за конституційною скаргою Дерменжи А.В. якщо Конституційний Суд України визнає неконституційність застосованого у справі скаржника положення закону, суди мають переглянути відповідні рішення, наслідком чого може бути повернення квартири чи виплата відповідної компенсації, тобто відсутній ключовий елемент незворотності наслідків ${ }^{2}$. Зрештою у справі за даною конституційною скаргою Конституційним Судом України було ухвалено Рішення від 17 липня 2020 p. № 8-p/2020 ${ }^{3}$, яким оспорюване положення ч. 1 ст. 23 Закону України «Про іпотеку» було визнано конституційним, а щодо ч. 2 ст. 23 зазначеного закону провадження було закрито.

Таким чином, у даному випадку забезпечувальний наказ не зміг допомогти суб'єкту праву на конституційну скаргу. В цілому ж практика Конституційного Суду України щодо застосування даного процесуального інституту лише почала формуватись і зміст критерію незворотності наслідків та характер «винятковості» випадків для його застосування встановлюватимуться саме практикою Конституційного Суду України через оцінний зміст зазначених категорій ${ }^{4}$.

Висновки. Внаслідок конституційної реформи правосуддя 2016 року було оновлено юрисдикційні повноваження Конституційного Суду України і ним вже напрацьовано певну практику стосовно їх реалізації, про що свідчать відповідні статистичні показники. Водночас у ході здійснення Конституційним Судом України своїх юрисдикційних повноважень щодо розгляду справ за конституційними поданнями, конституційними зверненнями $\mathrm{i}$ конституційними скаргами виникають певні проблемні моменти, пов'язані, зокрема, з: дотриманням формальних вимог Закону суб'єктами права на конституційну скаргу, дотриманням суб'єктами права на конституційну скаргу

\footnotetext{
${ }^{1}$ Ставнійчук М.I., Єзеров А.А., Запорожець В.І., Терлецький Д.С. (2019). Конституиійна скарга в діяльності адвоката. Харків.: Фактор, 74-75.

${ }^{2}$ Водянніков, О. (2019). Забезпечувальний наказ КСУ: щось пішло не так. LB.иа Блог Олександра Водяннікова. <https://lb.ua/blog/oleksandr_vodennikov/424996_zabezpechuvalniy_nakaz_ksu_shchos.html> (2020, жовтень, 08).

${ }_{3}^{3}$ Рішення у справі за конституиійною скаргою Дерменжи Андрія Вікторовича щодо відповідності Конституиії України (конституиійності) положень частин першої, другої статті 23 Закону Украӥни «Про іпотеку», 2020 (Конституційний Суд України). Конституційний Суд Украӥни Офіційний вебсайт $<$ http://www.ccu.gov.ua/sites/default/files/docs/8_p_2020n.pdf>(2020, жовтень, 08).

${ }^{4}$ Ставнійчук М.І., Єзеров А.А., Запорожець В.І., Терлецький Д.С. (2019). Конституиійна скарга в діяльності адвоката. Харків.: Фактор, 41.
} 
та на конституційне подання вимог Закону щодо обгрунтування відповідних тверджень, дотриманням строків конституційного провадження у справах за конституційними поданнями та конституційними скаргами, виконанням та фактичною реалізацією рішень і висновків Конституційного Суду України, відновленням порушених прав і свобод суб'єктів права на конституційну скаргу після ухвалення Конституційним Судом України рішень у їх справах. Вирішення зазначених проблем, в залежності від їх характеру, є прерогативою суб’єктів звернення, Конституційного Суду України, Верховної Ради України та ін.

\section{References:}

1. Zakon pro Konstytutsiinyi Sud Ukrainy, 2017 (Verkhovna Rada Ukrainy). [Law on the Constitutional Court of Ukraine, 2017 (Verkhovna Rada of Ukraine)]. Vidomosti Verkhovnoi Rady Ukrainy, 35, 376. [in Ukrainian].

2. Zakon pro vnesennia zmin do Konstytutsii Ukrainy (shchodo pravosuddia), 2016 (Verkhovna Rada Ukrainy). [Law on Amendments to the Constitution of Ukraine (Regarding Justice), 2016 (Verkhovna Rada of Ukraine)]. Vidomosti Verkhovnoi Rady Ukrainy [Information of the Verkhovna Rada of Ukraine], 28, 532. [in Ukrainian].

3. Postanova pro Rehlament Konstytutsiinoho Sudu Ukrainy, 2018 (Konstytutsiinyi Sud Ukrainy). [Resolution of Rules of Procedure of the Constitutional Court of Ukraine, 2018 (Constitutional Court of Ukraine)]. Ofitsiinyi sait Konstytutsiinoho Sudu Ukrainy [Official web-site of the Constitutional Court of Ukraine]. <http://www.ccu.gov.ua/sites/default/files/reglament_2.pdf> (2020, October, 07). [in Ukrainian].

4. Postanova pro Shchorichny informatsiina dopovid Konstytutsiinoho Sudu Ukrainy za 2017 rik, 2018 (Konstytutsiinyi Sud Ukrainy). [Annual information report of the Constitutional Court of Ukraine for 2017, 2018]. Ofitsiinyi sait Konstytutsiinoho Sudu Ukrainy [Official web-site of the Constitutional Court of Ukraine]. <http://www.ccu.gov.ua/sites/default/files/dopovid_2017.pdf> (2020, October, 07). [in Ukrainian].

5. Postanova pro Shchorichny informatsiina dopovid Konstytutsiinoho Sudu Ukrainy za 2018 rik, 2019 (Konstytutsiinyi Sud Ukrainy) [Annual information report of the Constitutional Court of Ukraine for 2018, 2019 (Constitutional Court of Ukraine)]. Ofitsiinyi sait Konstytutsiinoho Sudu Ukrainy [Official web-site of the Constitutional Court of Ukraine]. 〈http://www.ccu.gov.ua/sites/default/files/dopovid_2018.pdf> (2020, October, 07). [in Ukrainian].

6. Ofitsiinyi veb-sait Konstytutsiinoho Sudu Ukrainy. [The official website of the Constitutional Court of Ukraine] (2020). Golovna storinka [Homepage] <http://www.ccu.gov.ua> (2020, October, 07). [in Ukrainian].

7. Postanova pro Shchorichny informatsiina dopovid Konstytutsiinoho Sudu Ukrainy za 2019 rik, 2020 (Konstytutsiinyi Sud Ukrainy). [Annual information report of the Constitutional Court of Ukraine for 2019, 2020 (Constitutional Court of Ukraine)]. Ofitsiinyi sait Konstytutsiinoho Sudu Ukrainy [Official web-site of the Constitutional Court of Ukraine]. 〈http://www.ccu.gov.ua/sites/default/files/dopovid_2019.pdf> (2020, October, 07). [in Ukrainian].

8. Ukhvala pro obiednannia konstytutsiinykh provadzhen u spravakh za konstytutsiinymy podanniamy Verkhovnoho Sudu Ukrainy shchodo vidpovidnosti Konstytutsii Ukrainy (konstytutsiinosti) punktu 6 chastyny pershoi, punktiv 2, 13 chastyny druhoi, chastyny tretoi statti 3 Zakonu Ukrainy «Pro ochyshchennia vlady», 2017 (Konstytutsiinyi Sud Ukrainy). [Resolution on merging constitutional proceedings in cases on constitutional submissions of the Supreme Court of Ukraine on compliance of the Constitution of Ukraine (constitutionality) with paragraph 6 of part one, items 2, 13 of part two, part three of Article 3 of the Law Of Ukraine «On the purification of power», 2017 (Constitutional Court of Ukraine)]. Ofitsiinyi sait Konstytutsiinoho Sudu Ukrainy [Official web-site of the Constitutional Court of Ukraine]. 〈http://www.ccu.gov.ua/ sites/default/files/docs/5_yn_2017.pdf> (2020, October, 07). [in Ukrainian].

9. Polyakh ta inshi proty Ukrayiny, 2019 (Yevropeyskyy Sud z Prav Lyudyny) [Polyakh and others v. Ukraine, 2019 (European Court of Human Rights)]. Ofitsiynyy sayt Verkhovnoyi Rady Ukrayiny [Official site of the Verkhovna Rada of Ukraine)]. <https://zakon.rada.gov.ua/laws/show/974_e71\#Text> (2020, October, 07). [in Ukrainian].

10. Vysnovok po spravi pro Rymskyi Statut, 2001 (Konstytutsiinyi Sud Ukrainy) [Conclusion case on the Rome Statute, 2001 (Constitutional Court of Ukraine)]. Ofitsiinyi sait Konstytutsiinoho Sudu Ukrainy [Official web-site of the Constitutional Court of Ukraine]. http://www.ccu.gov.ua/docs/350 (2020, October, 07). [in Ukrainian]).

11. Rishennia u spravi pro provedennia mistsevoho referendumu v Avtonomnii Respublitsi Krym, 2014 (Konstytutsiinyi Sud Ukrainy) [Decision in the case of holding a local referendum in the Autonomous Republic of Crimea, 2014 (Constitutional Court of Ukraine)]. Ofitsiinyi sait Konstytutsiinoho Sudu Ukrainy [Official web-site of the Constitutional Court of Ukraine]. 〈http://www.ccu.gov.ua/ sites/default/files/ndf/2-rp/2014.pdf> (2020, October, 07). [in Ukrainian].

12. Rishennia u spravi shchodo vidpovidnosti Konstytutsii Ukrainy (konstytutsiinosti) Postanovy Verkhovnoi Rady Avtonomnoi Respubliky Krym «Pro Deklaratsiiu pro nezalezhnist Avtonomnoi Respubliky Krym i mista Sevastopolia», 2014 (Konstytucijnyj Sud Ukrayiny) [Decision in the case of compliance with the Constitution of Ukraine (constitutionality) of the Resolution of the Verkhovna Rada of the Autonomous Republic of Crimea «On the Declaration of Independence of the Autonomous Republic of Crimea and the city of Sevastopol», 2014 (Constitutional Court of Ukraine)] Ofitsiinyi sait Konstytutsiinoho Sudu Ukrainy [Official web-site 
of the Constitutional Court of Ukraine]. <http://www.ccu.gov.ua/ sites/default/files/ndf/3-rp/2014.pdf> (2020, October, 07). [in Ukrainian].

13. Kryminalnyi kodeks, ch. 4 st.. 382, rozd. XVIII, 2001 (Verkhovna Rada Ukrainy). [Criminal Code, Part 4 of Art. 382,chap. XVIII. 2001 (Verkhovna Rada of Ukraine)]. Ofitsiynyy sayt Verkhovnoyi Rady Ukrayiny [Official site of the Verkhovna Rada of Ukraine)]. 〈https://zakon.rada.gov.ua/laws/show/2341-14\#Text> (2020, October, 07). [in Ukrainian].

14. Hospodarskyi protsesualnyi kodeks, p. 1 ch. 3 st. 320, p. 4 ch. 1 st. 321, rozd. IV, hl. 3.1991 (Verkhovna Rada Ukrayiny). [Commercial Procedure Code, paragraph 1, part 3 of Art. 320, item 4 part 1 of Art. 321, chap. IV, ch. 3 . 1991 (Verkhovna Rada of Ukraine)]. Ofitsiynyy sayt Verkhovnoyi Rady Ukrayiny [Official site of the Verkhovna Rada of Ukraine)]. 〈https://zakon.rada.gov.ua/laws/show/1798-12\#Text〉 (2020, October, 07). [in Ukrainian].

15. Tsyvilnyi protsesualnyi kodeks, p. 1 ch. 3 st. 423, p. 4 ch. 1 st. 424, rozd. V, hl. 3, 2004 (Verkhovna Rada Ukrayiny). [Civil Procedure Code, paragraph 1, part 3 of Art. 423, item 4 part 1 of Art. 424, chap. V, ch. 3. 2004 (Verkhovna Rada of Ukraine)]. Ofitsiynyy sayt Verkhovnoyi Rady Ukrayiny [Official site of the Verkhovna Rada of Ukraine)]. 〈https://zakon.rada.gov.ua/laws/show/1618-15\#Text> (2020, october, 07). [in Ukrainian].

16. Kodeks administratyvnoho sudochynstva, p. 1 ch. 5 st. 361, p. 4 ch. 1 st.363, rozd. III, hl. 3, 2005 (Verkhovna Rada Ukrayiny). [Code of Administrative Procedure, paragraph 1, part 5 of Art. 361, item 4 h. 1 Art. 363, chap. III, ch. 3. 2005 (Verkhovna Rada of Ukraine)]. Ofitsiynyy sayt Verkhovnoyi Rady Ukrayiny [Official site of the Verkhovna Rada of Ukraine)]. 〈https://zakon.rada.gov.ua/laws/show/2747-15\#Text> (2020, October, 07). [in Ukrainian].

17. Kryminalnyi protsesualnyi kodeks, p. 1 ch. 3 st. 459, p. 1 ch. 5 st. 461, rozd. V, hl. 34, 2012 (Verkhovna Rada Ukrainy). [Criminal Procedure Code, paragraph 1, part 3 of Art. 459, item 1 part 5 of Art. 461, chap. V, ch. 34. 2012 (Verkhovna Rada of Ukraine)]. Ofitsiynyy sayt Verkhovnoyi Rady Ukrayiny [Official site of the Verkhovna Rada of Ukraine)]. 〈https://zakon.rada.gov.ua/laws/show/4651-17\#Text〉 (2020, October, 07). [in Ukrainian].

18. Stavniichuk, M. I., Yezerov, A. A., Zaporozhets, V. I., Terletskyi, D. S. (2019). Konstytutsiina skarha v diialnosti advokata [Constitutional complaint in the activities of a lawyer]. Kharkiv: Faktor. [in Ukrainian].

19. Vodiannikov, O. (2019). Zabezpechuvalnyi nakaz KSU: shchos pishlo ne tak. [Security order of the CCU: something went wrong]. LB.ua Bloh Oleksandra Vodiannikova [LB.ua Blog of Alexander Vodyannikov]. <https://lb.ua/blog/oleksandr_vodennikov/424996_zabezpechuvalniy_nakaz_ksu_shchos.html> (2020, October, 07). [in Ukrainian].

20. Rishennia u spravi za konstytutsiinoiu skarhoiu Dermenzhy Andriia Viktorovycha shchodo vidpovidnosti Konstytutsii Ukrainy (konstytutsiinosti) polozhen chastyn pershoi, druhoi statti 23 Zakonu Ukrainy «Pro ipoteku», 2020 (Konstytucijnyj Sud Ukrayiny) [Decision in the case on the constitutional complaint of Dermenzha Andriy Viktorovych regarding the compliance of the Constitution of Ukraine (constitutionality) with the provisions of parts one and two of Article 23 of the Law of Ukraine «On Mortgage», 2020. (Constitutional Court of Ukraine)]. Ofitsiinyi sait Konstytutsiinoho Sudu Ukrainy [Official web-site of the Constitutional Court of Ukraine]. <http://www.ccu.gov.ua/sites/default/files/docs/8_p_ 2020n.pdf> (2020, October, 07). [in Ukrainian]. 